\title{
Mainstreaming Islamic Religious Education and Secular Education in Schools as Per the Kenyan Basic Education Act 2013
}

\author{
Ahmed A. Osman \\ Department of Education \\ School of Education, Arts and Social Sciences, Garissa University, Kenya \\ Mohamed Mahat Ali \\ Department of Education, School Of Education, Arts And Social Sciences, Garissa University, Kenya
}

\begin{abstract}
This paper is an attempt to harmonize the local Quranic schools, the Islamic schools (Madarasa) and the secular schools in Kenya. The article is based on existing literature review, the author's personal experiences and opinions. It is felt that a change be made to integrate the three-parallel curricula. The curriculum of the Quranic and the Arabic schools can be accommodated into the secular curriculum to give time for the pupils for rest or play or do their homework adequately. The current system makes the child run from one school to another. This starts at the age of six and continues until the child completes primary school. This is strenuous for the child.

It is hoped that the integrated approach will alleviate this problem. The child needs to be given a chance to interact with his $\backslash$ her environment so that he $\backslash$ she can react to it. It should be concerned with the intellectual, emotional, physical and social growth of the child.
\end{abstract}

Keywords: Quranic Schools, integrated curriculum, secular education, colonial administration

DOI: $10.7176 / \mathrm{JEP} / 10-27-10$

Publication date:September $30^{\text {th }} 2019$

\section{Introduction}

Kenya had both traditional and Islamic education before the coming of the Europeans. The main goal of these systems was to train the individual to fit into the society. At the end of the ninetieth century, the missionaries introduced formal education (western education) where learning and teaching were formalized into classroom situation. Missionary education was linked to Christianity and the first aim was to produce African 'priests' to spread evangelism.

The Africans were to be enlightened so that they could read the Bible and assist in the spread of Christianity and western civilization to fellow Africans. Africans were also taught to read and write so that they could serve as interpreters for the missionaries and the colonial government.

The missionary control of education continued in Kenya for a long time. The introduction of school and its influence faced the Africans with difficulties that remain unsolved today.

The chief of this is the need to create an education system suited to their needs. Neither the missionaries nor the colonial administration made any attempt to link education to Africans problems and cultural heritage (Eshiwani, 1993).

In Islam, learning was made compulsory to both male and female. A well-known saying of the prophet of Islam was "the search for knowledge is a duty of every Muslim male or female"(Doi, 1979). Both the Qur'an, and the Hadith made references where learning is encouraged and the learned given preference position of honor. Seeking knowledge is regarded as one of the meritorious act of worship that a Muslim can perform. Islamic educationists define the aims of education as to initiate the people into worthwhile activities, but these activities are defined according to the Islamic moral judgment. "The goal is to produce responsible citizens who are conscious of their duties and their commitments to the service of their society... It investigates all aspects of life, spiritual, material and intellectual with an aim to improve it" (Ahmad, 1968, p. 5). The aims and concepts of Islamic education in Kenya have been the same as those laid down by the early Muslim scholars.

Islamic education was simultaneously introduced with the religion of Islam. Islam played a major role in the shaping of culture and education in most African countries. "Wherever Islam spread rudimentary knowledge of the Qur'an and the Hadith (prophetic traditions) and the Sharia are still taught to its followers..."(Fafunwa, 1982, p.11). Islamic education began on the prophetic advice that, "the best man among you is the one who learns the Qur'an and cares to teach it" (Doi, 1979, p. 90). Teaching religion to others was considered a duty for which the person should expect no monetary or non-monetary reward from others. This noble principle was successfully applied at the early stage of development of Islamic education. The Islamic school in Kenya was referred to as Qur'anic schools. A Qur'anic school is usually found in and outside the mosque "the oldest Muslim university, Al-Azhar in Cairo was established in a mosque" (Alao, 1993, p.108). 


\section{The Quranic School System}

As early as the fifth year of their lives Muslim children are expected to start their first stage of Quranic education. At this stage the pupil learns the shorter chapters of the Qur'an by rote. The only pleasure they can derive from the system at this stage lies in the choral recitations, which often follow a sing-song pattern. The pupils enjoy reading the verses to themselves in their homes and at play. The method of instruction is that the teacher recites to his pupils the verses to be learned and they repeat after him. The teacher does this several times until he is satisfied that they have mastered the correct pronunciation. The pupil is left on his own to continue repeating the verses until he /she has thoroughly memorized it. The verses are then linked with the previously memorized verses and in this way the pupil learns by heart all the chapters of the Qur'an. In the Quranic schools, unlike formal schooling, there are no codified rules but there are few conventional behavior which guide the pupils.

The duty of the teacher was primarily to train them to be good citizens. The school week starts on Saturday and ends on Thursday. There was no bell to summon the pupils to school, nor was there a fixed dress. Another unique feature of the Islamic education was that there was no funding problem, no overheads. It was education for humanity not education for sale or employment market.

\section{Western versus Islamic Education}

There was discrimination in colonial school system where colonial administrators colluded with the missionaries in ensuring that secular education was going to be maximally benefit non-Muslim sections of the population. There was resistance to an education system that was to de-Islamize and de-culturize the Muslims. The choice opened to the Muslims was either apostasy or total rejection of the new system of education and the overwhelming majority of Muslims chose the latter. "The common observation was that there was a conscious effort and an obvious attempt by the colonial government to exclude Muslims from the western education," (Bakari, 1983, p. 83).

Muslims found themselves falling behind in western education during the colonial period. It was only after independence that schools were opened for the Muslims that were offering both the secular class alongside some lessons in Islam. But the Qurainc schools continued flourishing. The child attended secular school in the morning and the Quranic school late in the evening. In the late 1970's very many students of the Quranic schools were offered scholarships to study in Saudi Arabia and Kuwait. After completion of their studies they were sent back to Kenya to establish Islamic schools in line with the curriculum of those countries.

The Islamic schools flourished in areas dominated by Muslims. There were no fees charged in these schools and Gulf countries paid for both the teachers and the physical facilities. The parents not wanting to miss this chance enrolled their children into the schools. The child had to attend three schools at different times. He / she had to go to the secular school in the morning, the Islamic school Islamic school late in the afternoon and the Quranic school in the evening.

The secular school and the Islamic school were two parallel schools that taught the same thing but in different languages. Students learned mathematics, science, geography, history, Fiqh (Jurisprudence), Quran and Arabic language. While in the secular school they were taught English language, Swahili, science, social studies, mathematics, arts, crafts, home science, music, business education, Islamic Religious Education and Physical Education. This crowded timetable does not give the child enough time to play and do homework. It is felt that the three schools could be harmonized or integrated so that the child could receive the same lessons in the secular schools and grow up to be a good Muslim.

\section{Defining Curriculum}

Curriculum is defined in many ways. It is defined as a plan for action, or a written document that includes strategies for achieving the desired goals or ends. Galen Saylor defines curriculum as a plan for providing sets of learning opportunities for persons to be educated. It is an organized set of formal education and training intentions. Wiles and Bondi see it as a plan for learning whereby objectives are determined by what learning is important. Hass contends that curriculum is all the experiences that the individuals have in a program of education which is planned in terms of theory and reason or past and present professional practice ( In Orstein \& Hunkins, 1993). Brubaker (1982) defines curriculum as what a person experiences in a setting. This includes all the instructions among persons as well as the interactions between persons and their physical environment.

\section{Proposed Change in the Curriculum}

Change occurs in three stages. The first stage is the initiation stage, in which ideas for change are launched and decisions are made regarding the nature, direction, and extent of change.

The second stage is said to be one of legitimization, in which the sentiment on behalf of change is communicated. The third stage involves congruence of the separate systems of values held by the person or persons seeking to create change and by the persons who are the targets or subjects of the proposed change (Bennis, 1978). The process of change may be assisted by permissiveness and support in accordance with a 
helpful human relations approach. It may also be aided temporarily by manipulating extrinsic rewards such as affection, favor, promotion, and additional income.

The process of change may be viewed from any of these three different perspectives. The first of these is the technical. According to this perspective, an innovation can be designed carefully and put into action in a rational manner and with all necessary technical assistance. The second perspective is commonly called the political, leads to identification of the special interest of the participants in the planning. This perspective has to do with the nature of the people's incentives and their relative power within a political setting. When the technical perspective fails to account for failures that develop, attention is drawn to the interaction of participants in a political milieu. The third perspective is the cultural one; this locates each proposed change within a complex of beliefs, norms, and values. Each change no matter how small has a potential for disturbing or altering culture.

In applying the concept of the change process to the integrated program, this brief description contains several ideas that need examination and extension into the practice in the schools. When the ideas have passed through the sieve of the educator's experience, they become a set of tentative principles like the following; People improve with greatest enthusiasm when they detect a desire on the part of the stimulator of improvement to improve himself or herself. The argument "you need improving and I am here to improve you" has very little effect. "We have a common problem, to solve it, we should all improve our competencies; the direction of improvement should be determined cooperatively.

The changes that would be done is expected to be acceptable to the parents. A solution will be found to a long-standing problem. The parents would like their children to benefit from the three systems. This new approach will be more helpful to the child and give him/her time to concentrate in his / her studies. The teachers with experience in curriculum planning will be consulted before the planned change.

This new program can be tried as a piloting project before it is disseminated to other schools. Doll (1992) suggests the following in improving curriculum;

-Work with people not over them.

- Show that you too desire to improve.

-Help people with whom you work, know you and know each other.

-Help teachers enjoy a variety of in-service experiences

-Work with both individuals and groups, balancing your time between individual conference and group work.

- Keep channels of communication open.

-No matter what is done to help individuals change, the expenditure of time and the occasional presence of turmoil appear to be constant in the process (Red \& Shainline, 1987). Jenkins (1976) asserts that change will occur only if forces are modified so that the level where the forces are equal is changed.

To modify the forces one may reduce or remove restraining forces or change the direction of certain forces. For instance, one may remove lack of skill in teacher pupil planning through training, strengthening or add to competence planning. In analyzing the field forces the change agent of the curriculum may seek answers to the following questions. What forces are there in the field? Can the direction of some of the forces be reversed or altered in another way? Which restraining forces can probably be reduced with the least effort? Which can be increased?

Guba (1978) believes that it is possible and necessary to have a strategy of diffusion of innovation. As a technique the strategy can utilize telling, showing, helping, involving and training. It is therefore necessary to involve members of the community, the teachers, the school board, and the politicians in the planned change.

The teachers are obviously very important in initiating and perpetuating change. It is through their effort that the program can succeed rapidly. Changes that are judged to be improvement are produced at several levels of operation. Improvement can be accomplished by substitution, alteration, variation, restructuring or value orientation change. Changing teachers' roles in this way requires a shift in their values, a shift that adults must make with difficulty, though they give temporarily signs of having made it.

After having outlined the proposed change in the program, the goals of education have to be revisited. It is expected that the new program should fit with previously established goals of education. If necessary the aims will be reviewed.

\section{Goals of the Integrated Program}

Whether planning for one classroom or many, curriculum scholars must have a clear idea of what they expect students to do. Establishing goals is an important and necessary step because there are many desirable things that students could learn more than schools have time to teach them so that schools should spend valuable instructional time only on high priority learning (Ronald, 1983). The philosophy of the school usually guides us to determine the goal, which may be preceded or followed by need assessment. Indeed, the goals must reflect policy, present, future conditions, priorities, resources available, awareness of the constitution, desire and needs.

These goals are derived from different sources. Tyler (1949) asserts that, there are three sources of educational objectives; studies of the learners themselves, needs and interest, studies of contemporary life 
outside the school, and subject specialist. The first one is the use of a social and educational philosophy and the second one is the use of philosophy of learning. Every philosophy has its own goals which are derived from its theory, for example, the objective for essential theory is to promote the intellectual growth of the individual, to educate the competent person whereas the aims for progressivism theory is to promote democratic and social living.

Therefore, the objectives of the integrated program are to:

- $\quad$ Acquire literacy, numeracy and manipulative skills.

- Develop self-expression, self-discipline, self-reliance and full utilization of the child's senses.

- Develop ability for clear logical thought and critical judgment.

- Experience a meaningful course of study that will lead to enjoyment and successful learning and a desire to continue learning.

- Prepare the learner to make positive contribution to the development of the society.

- Enable the learner to choose with confidence and cope with vocational education after school.

- Lead to the acquisition of attitudes of national patriotism, self-respect, self-reliance, co-operation, adaptability, sense of purpose, integrity and self-discipline, respect and consideration for others, loyalty and service to home, society and the nation.

- $\quad$ Provide increased training opportunities for school leavers that will enable them to be self-supporting.

- Develop practical skills and attitudes, which will lead to income earning activities in the urban or rural areas through salaried employment or self-employment.

- $\quad$ Provide the technical knowledge and vocational skills necessary for the growth of agriculture, industry and commerce development.

- $\quad$ Produce people who can apply scientific knowledge to the solution of environmental problems.

\section{Philosophical Foundation}

Philosophy is a key role in curriculum selection because it influences the objectives and content as well as the organization of the curriculum. Philosophy concerns itself with the large aspects of life, the problems and prospects of living and the way we organize our thoughts and facts.

It consists of searching for defined and defensible values; clarify one's beliefs and attitudes and formulating a framework for making decisions and acting on those decisions. Philosophy gives educators, especially the curriculum workers a model or foundation for organizing schools and classrooms. It helps to answer what schools are for, what subjects are of value, how students learn, and what methods and materials to use (Ornstein \& Hunkins, 1993)

Essentialism philosophy is best suited for the integrated program, because it is a traditional philosophy that is rooted in both idealism and realism. According to essentialist, the school curriculum should be geared to the fundamentals or essentials of the three Rs at the elementary schools. The child should master the skills that form the basis of the subject matter. Another philosophy that might be important in the development of this program is progressivism. Progressivism was part of the movement to education reform in the United States. John Dewey and his most comprehensive work, Democracy and Education (1902) are rooted in this philosophy. Dewey wanted the school to become the social center of urban industrial society. He believed that the specialization of industry and growth of large urban centers destroyed a sense of community and alienated people from one another.

To counter these trends, he wanted the school to serve as a social center that will bring together the urban community by providing space of community gatherings, creating a sense of inter-dependence and building a spirit of cooperation (Spring, 1994).

According to progressivism the outlined skills and tools of learning include problem-solving methods, scientific-inquiry, learning experiences should include cooperative behaviors and self-discipline. Dewey asserts that these skills and experiences in the schools can transmit the culture of society while it prepares the students for a changing world because reality is constantly changing. He saw no sense in focusing upon fixed body of knowledge (Ornstein \& Hunkins, 1993, Spring, 1994). Progressivism placed heavy emphasis on how to think not what to think. The role of the teacher was unique when operating under progressivism thinking. The teacher is to serve as a guide for the students in their problem solving. In the integrated curriculum the child is expected to learn through problem solving and the emphasis is what the child learns should be practical and realistic for both the society and for himself $\backslash$ herself.The students just like in the progressivism philosophy are expected to work in-groups. This will be acceptable to the Muslim parents since Islam encourages communal life than individualism.

\section{Psychological Foundations}

One of the psychological foundations of this program is humanistic. Humanistic psychology breeds an environment of understanding, compassion, encouragement and trust. 
It encourages freedom in the form of student mobility, increased choice of curricular activities and learning by doing format. This program held that children are best prepared for adult life by fully experiencing childhood.

Children are led naturally into more traditional areas of schooling only after experiencing a curriculum of physical exercise, nature study, music, and field geography, story-telling, fundamental conception of numbers, drama and games.

Curriculum is geared to the maturational levels of students and teachers serve as guides to learning rather than authority figures or conveyors of knowledge. The problem solving process of instructional format borrows heavily from another humanistic design, the core curriculum.

The emphasis of the core curriculum is the continuity of the teacher-pupil relationships. Humanistic design are generally characterized by highly flexible instructional areas, high degrees of student involvement and an emphasis on the process of learning as opposed to a product orientation or a preparation for life outlook.

The present school curriculum in Kenya has failed miserably because the emphasis is learning and discipline. The teachers and the schools control students not for their own good but for the good of adults (Eshiwani, 1993).

Humanistic psychology attempts to form more meaningful relationships between students and teachers. The humanistic theory is expected to foster students' independence and self-direction and promote greater acceptance of self-and others.

The teacher's role would be to help learners cope with their psychological needs and problems to facilitate self-understanding among students and to help them develop fully. Cognitive psychology will also be useful for the program because it involves in growth and development in the structure and functions of human characteristics.

These changes are said to occur in a steady progression. They are not uniform but result from interaction of inherited potential and environment (Ornstein \& Hunkins, 1993). Environmental experiences are the key to cognitive psychology. It is the role of the teacher to shape the actual experience by knowing what surroundings are conducive to having experiences that lead to growth.

My theory will borrow from Tyler's three methods of organizing learning experiences. The curriculum should have continuity, the skills and concepts learned should be recurring and there should be continuing opportunity for the skills to be practiced. The learning experiences must be designed to match the age level at which certain process of thought can occur.

The idea is to transform complex concepts and subject matter into mental operations appropriate to the learner and to provide for increasing deeper and more formal levels of thinking (Taba, 1962).

\section{Social Foundations}

In discussing the integrated curriculum it is worthwhile to discuss the social setting especially the relationship between schools and society and its influence on curriculum decisions.

Curriculum decisions take place in complex social settings, through demands that are imposed by society and that filter down to schools. Schools are more than any other institutions in society agents of social change. The school curriculum is often evaluated in terms of its response to the social issues of the day. This orientation envisages great changes in society and demands that curriculum provides the necessary tools for the individual to survive in what appears to be an unstable and changing world. The curriculum in use must not only enable the individual to cope with change, but also be such that it aids the education of the individual to intervene actively to shape the changes in society.

Although education is neutral, it has been used to promote one type of political institution. The kind of education Kenyans receive determines the quality of their society. The transmission of culture is the primary task of a society's educational system. The values, beliefs, and norms of a society are maintained and passed to the next generation not by teaching about them but also by embodying them in the very operation of the educational system.

The overall and central argument in this curriculum orientation is that the proponents see schooling as an agency for social change.

The integrated curriculum should therefore be relevant both to the students' interest and society needs since curriculum is conceived to be an active force having direct impact on the whole fabric of human and social context. Curriculum should be based on the precepts of the students asking: "What kind of person am I now?

What kind of person will I become if the present habits and trends continue in our society? What can be done by schools through their curriculum to change odd and unhealthy tendencies and preferences that conflict with societal norms?” (Orstein \& Hunkins, 1993).

\section{The Role of the School}

In all countries the schools are held responsible for children's education. Schools' function and goals have improved through the centuries. 
The process and the aims of school differ from one theory to another. For example the progressive see the school as a microcosm of a larger society. The school should not be seen as a distinct social setting in which education takes place in a unique way.

Learning is constantly taking place in a person's life.

This learning experience takes place in the same manner inside the school as they do in the world at large.

\section{Restructuring the Content}

In curriculum planning it is important to understand the nature of the content, but also to consider its relation to the educational goals. Dewey and other pragmatist were of the opinion that curriculum should not be divided into subject-matter areas but should be built around natural units that grow out of the pressing questions and experience of the learners.

In contrast, essentialism theory stresses that curriculum content should contain the basis of education reading, writing, arithmetic, history and foreign language (Knight, 1989). Doll (1992) suggests that the teachers' decision on content selection should be guided by these considerations; the nature of the learner, the learning process, the impact of society at large and the local community upon the school.

The question is what knowledge is most worth? This is the question that will be asked by every generation of teachers.

It is important to integrate the three parallel systems (the Quranic, Arabic and secular schools) and come up with an eclectic curriculum that is acceptable to both the parents and the Ministry of Education.

The most important subjects will be taken from the Arabic school and integrated into the secular school timetable. These are Quran, Arabic language, Fiqh and Islamic history.

These subjects can comfortably be integrated into the western school system by reducing the number of lessons in the non-essential subjects. The school day will begin on Monday and end on Friday.

On Saturday and Sunday the child will be free. This will give him/ her enough time to rest, do homework and report back to school on Monday ready for school.

The children in the upper primary will continue to have nine lessons every day and with the integrated program still manage to have time for games and club meeting after classes.

The number of lessons for the week has remained the same except some have been put together.

These new changes will also be acceptable to the Ministry of Education because it meets the broad aims of their curriculum.

The school's daily routine will be the following; (This is for upper primary classes 4-8).

- $\quad 7.00$ a. m. all students report to school.

- 7.10-7.25 a.m. school assembly (This will be for Monday, Wednesday and Friday, Tuesday and Thursday class teachers will meet their students to listen, advice and help those students who may have problems)

- $\quad 7.30---8.05$ a.m. first lesson

- $\quad 8.05--8.40$ second lesson

- $\quad 8.40---9.15$ third lesson

- 9.15---9.50 fourth lesson

- $\quad 9.50$---10.20 break (30 minutes recess)

- $10.20---10.55$ fifth lesson

- 10.55--11.30 sixth lesson

- 11.30---12.05 seventh lesson

- 12.05---2.45 lunch

- $\quad 3.00---3.35$ p.m. eighth lesson

- $\quad 3.35---4.20$ ninth lesson

- 4.20---Games / club meetings/ go home 
The upper primary timetable (class 4-8) will be as stipulated below;

\begin{tabular}{|l|c|}
\hline Subjects & No. of Lessons/week \\
\hline English language & 7 \\
\hline Mathematics & 7 \\
\hline Science & 4 \\
\hline Kiswahili & 5 \\
\hline Social Studies & 3 \\
\hline Islamic History & 3 \\
\hline Fiqh & 3 \\
\hline Arabic language & 6 \\
\hline Qur'an & 6 \\
\hline Creative Arts & 3 \\
\hline P.E. & 3 \\
\hline Total lessonslweek & 50 \\
\hline
\end{tabular}

\section{The Role of the Teacher}

A teacher according to the essentialist theory is the focus of the classroom authority. The essentialists hold that the teacher is not a fellow learner or a guide but rather the one who knows what the student needs to know. What is good for the logical order of the subject matter and the way it should be presented (Rich, 1992).

The teacher as a representative of the adult community is in a position that demands respect. If this respect is not forthcoming, the teacher has the right and responsibility to use disciplinary measures that will lead to an atmosphere conducive to orderly learning (Knight, 1989).

According to the progressive theory, the teacher's role is that of an advisor, a guide and a fellow traveler, rather than that of an authority and classroom director. The role of the teacher can be seen as that of helping students learn how to learn by themselves so that they will develop into self-sufficient adults in a changing environment (Ornstein \& Hunkins, 1993).

In the integrated program a teacher is seen as a guide as well as the locus of classroom authority and one who should diagnose and evaluate the programs in areas of organized knowledge, basic skills, personal development and social interaction.

The teacher should be able to lead his $\backslash$ her students beyond the narrow realm of their field of study as they stimulate genuine thought concerning the relationship of their literary specialty to the ultimate meaning of mankind and the universe. It is important for the teacher to make relationship with the student outside the classroom if he $\backslash$ she is to succeed inside it. A close personal relationship between student and teacher enhances learning, which is the ultimate goal of the school.

The teachers should also make use of the experiential background of the child in the learning situation. This means that an attempt should be made to identify those experiences to facilitate learning at the students' present stage of development. In order to play an effective role in the education of his $\backslash$ her students the teacher should be sincere in his $\backslash$ her work by reaching the truth rather than desiring it. The teacher needs to be patient since students are not equal in their abilities to learn. They must admit the students to a level of equality in the classroom interaction. Although the teacher is in a position of superiority with regard to the organization of the learning situation, once the discussion has begun both teacher and student are equal in the quest for truth. Usually the teacher will exercise leadership by virtue of superior maturity, knowledge, or skill but must never use the superiority of rank to alter the logical superiority of the student's argument. The teacher must not use his $\backslash$ her position of authority to force even verbal acceptance of doctrines that the students have no opportunity to study or criticize, even if the teacher is himself convinced of the truth of the doctrines.

\section{The Role of the Student}

The child is the starting point, the center and the end of the curriculum. The goal of the school is his $\backslash$ her total development, his $\backslash$ her growth not knowledge but self-realization of the individual is the central theme (Dewey, 1902). Kliebard (1987) asserts that, when the learning activities are matched with the learner's natural development the result will be more effective learning. The rationale being helping the learner to see the whole if they are to derive meaning from the subject matter.The student is the most important factor in the learning process, in addition to the teacher and the curriculum. These factors must interact together to help students meet their educational objectives.

The teachers should guide students in the classroom to achieve the required knowledge by developing useful methodologies and group work or by giving every student an appropriate assignment individually. 
Although individual differences exists in all levels, these differences should be used to guide the learners in the learning process so that it can serve students in meeting their educational needs, interest and abilities.

\section{Implementation of the Program}

The basic rule in implementing change is to avoid implementing and planning at the same time. Those who try to plan and change at the same time may find themselves where they started.

As implementing progresses, the change becomes threatening. If those most directly involved in the change, teachers in this case are allowed changing plans as they implement each time they are threatened they will change directions to a more comfortable position.

The change is back to the old, secure practice. Given time they will be back where they started in that comfortable secure place (Kimbrough \& Burkett, 1990).Implementation of the integrated program will start in the kindergarten schools. Both the Arabic and the secular schools have these types of schools that can be used in the trial stage.

The opinion leaders and Imams of the local mosques can also be involved because these are the areas where resistance can easily come from because of their position in the community.

The Sub county Education Officer and the Quality Assurance \& Standard Officers (supervisors) need to be involved so that the program can have their support. It is always easy to plan change compared to implementing it. The teachers and the school principals are the most affected during this period. Even if the change agent may be championing the change at the beginning he /she may feel threatened at the implementation stage. If she/ he is a weakling he / she may not survive as an agent of change in the long run. For the change to be effective the change agent has to know what he/ she wants to do, plan carefully and pursue the change with zeal.

\section{Evaluation}

Evaluation may be defined as a broad and continuous effort to inquire into the effects of utilizing educational content and process to meet clearly defined goals.

According to this definition, evaluation goes beyond simple measurement and also beyond simple application of the evaluator's values and beliefs.

The integrated program has to be evaluated to determine whether the major curriculum changes made have constituted real improvement. In writing about evaluation for curriculum improvement Oliver (1988) identified three thrusts: within the curriculum, about the curriculum, as in evaluation of the curriculum's success in reaching its goals, and about the process used in improving the curriculum. According to Talmadge (1985), the common reasons for wanting to evaluate curriculum improvement programs and projects may be stated as follows;

I'd just like to know whether this plan has been worth anything (evaluation to satisfy ones curiosity).

"I may be asked whether the time, talent, and money expended on this project have yielded results." (Evaluation to fulfill an accountability requirement)

"I wonder how our plan compares with theirs" (comparison of programs).

"We need to know how nearly ideal this plan is" (evaluation to distinguish among the best).

"We want to know what moves to make next" (decision evaluated). In order to determine whether the integrated program was a success or not, the teachers and school administrators will evaluate pupils' progress, the evaluation of the program by outside agencies and an evaluation by the Ministry of Education.

But the classroom is the most important data gathering that leads to curriculum improvement which assists with the evaluation of projects already under way.

\section{Conclusion}

This curriculum plan is based on the concept of integration. The child is seen as the center of this curriculum and his $\backslash$ her interest and freedom must be put into consideration. The child needs to be given a chance to interact with his $\backslash$ her environment so that he $\backslash$ she can react to it.

It should be concerned with the intellectual, emotional, physical and social growth of the child. The child is also expected to be useful to himself $\backslash$ herself after the completion of the school by either seeking wage employment or be self-employed. What is taught in the classroom results from confluence of several oftenconflicting factors.

In improving curriculum needs one has to understand the politics of curriculum. The way organizations and individuals influence what is taught in the schools. But this should not jeopardize the objectives of the curriculum and the desired end of the learning.

These factors should be seen as a collaborative effort to help the child reach a level of maturity and acquire the necessary skills. 


\section{References}

Ahmad, K. (1968). Principles of Islamic education. Karachi. Islamic Publications.

Alao, A. (1993). Education in Islam. The Challenge of Numbers, Breath an Quality.

In Akali N. et al.(ed.) Islam in Africa, Proceedings of Islam In Africa Conference. Lagos. Spectrun Books Limited.

Bakari, M. (1993). The Prospect of Shari'a in East Africa. In Alkali, N. et al (ed.) Islam in Africa, Proceeding of Islam in Africa Conference. Lagos.Spectrum Books Limited.

Beauchamp, G. A. (1961). Curriculum Theory. Wilmette, Illinois. The Kagg Press.

Brubaker, D. (1982). Curriculum Planning, The Dynamics of Theory and Practice. Glenview, Illinois. Scott \& Foresman.

Doi, A.(1970). Introduction to Hadith. Lagos. Islamic Publication Bureau.

Doll, R. C. (1993). Curriculum Improvement Decision Making Process. Boston. Allyn and Bacon.

Dewey, J. (1944). Democracy and Education. New York.

The Free Press. (1902). The Child and The Curriculum. Chicago. University of Chicago Press.

Eshiwani, G. (1993). Education in Kenya since Independence. Nairobi. East Africa Publishing House.

Fafunwa, B. (1982). African Education in Perspective. In Fafunwa \& Aisi (ed.).Education in Africa. A Comparative Survey. London. George Allen \& Unwin.

Guba, E. G., (1978). “Diffusion of Innovation,” Educational Leadership 25, no.4 p.292-295.

Gress, J. R. (1978). Curriculum: An Introduction to the Field. California.

Kimbrough, R. B. \& Burkett, C. W. (1990). The Principalship: Concepts and Practices. Eaglewood Cliffs, New Jersey. Printice Hall.

Kliebard, H.M. (1987). The Struggle of the American Curriculum 1893-1958. New York. Routeldge \& Kegan Paul. Knight, George, R. (1989). Philosophy and Education. Andrews University Press.

Laska, J. A. ( 1976). Schooling and Education, Basic Concepts and Problems. New York, NY: D. Van Nolstrand Company

Orstein, A. (1978). An Introduction to the Foundation of Education. Chicago. Menally College Company.

Ranald, S. \& Tyler, R (1983). Foundation Curriculum Decision, Goals and Objectives. ASCD, Yerabook.

Rich, John.(1992). Foundations of Education on American Education. New York. Macmillan Publishing Company.

Rose, Arnold. "Generalization in the Social Sciences.” American Journal of Sociology, 59: 52, August, 1953. 